\title{
Comparative study of sublingual versus vaginal misoprostol following mifepristone in early first trimester medical termination of pregnancy - a prospective study
}

\author{
B. L Pathak, Shikha Hajong Roy \\ Correspondence: Dr Shikha Hajong Roy, MS Obst and Gynae, J-505, Rohan Vasantha, \\ Varthur Main Road, Marathalli, Bangalore-560037, Karnataka, India; \\ Email - dr.shikha.hajong@gmail.com \\ Distributed under Attribution-NonCommercial-ShareAlike 4.0 International (CC BY-NC-SA 4.0)
}

\begin{abstract}
Aim: To compare the efficacy and side effects of sublingual versus vaginal administration of misoprostol after a single oral dose of $200 \mathrm{mg}$ of mifepristone in termination of early first trimester pregnancy. Methods: This is a randomised prospective study comparing the use of sublingual misoprostol with vaginal misoprostol in combination with mifepristone for termination of pregnancy up to 63 days. A total of 100 women who requested legal termination of pregnancy were randomised into two groups and given $200 \mathrm{mg}$ of oral mifepristone followed 48 hours later by either 800 microgram of sublingual $(n=50)$ or vaginal $(n=50)$ misoprostol. Results: Complete abortion occurred in $96 \%$ of women in the sublingual group and $94 \%$ in the vaginal group. There was no case of ongoing pregnancy or missed abortion. The median duration of bleeding was 14.65 days in sublingual group and 14.96 days in vaginal group. There were no serious complications reported. Fever, chills and gastrointestinal side effects (nausea and diarrhoea) were significantly more common in the sublingual group. Conclusion: The combination of mifepristone and misoprostol is effective for medical abortion up to 63 days of gestation. Both the sublingual and vaginal are effective routes of administration. Further randomised trials are required to find out the optimal dose of sublingual misoprostol that can give the highest complete abortion rate and lower incidence of side effects.
\end{abstract}

Keywords: Mifepristone, misoprostol, medical abortion.

The history of induced abortions is as old as the history of mankind. Aristotole in Greece (384-322 BC) accepted abortion as a permissible act and advocated that parents with sufficient number of children should be allowed to procure abortion before the mother gets the sensation of a living baby inside the uterus ${ }^{1}$. Contraception may be used incorrectly, yet even when used properly, no method is $100 \%$ effective. Induced abortion is the third commonest means of fertility control next to sterilisation and oral contraceptives ${ }^{2}$. Medical Termination of Pregnancy (MTP) Act has legalized termination of such an unwanted pregnancy in India in 1971. The statistics of abortions are grossly inadequate, as only legal abortions are reported and the ratio of legal to illegal abortions vary from 2:1 (ICMR) to 10:1 . The maternal mortality attributed to abortions in India is

Received: $28^{\text {th }}$ March 2018. Accepted: $9^{\text {th }}$ August 2018.

Pathak BL, Roy SH. Comparative study of sublingual versus vaginal misoprostol following mifepristone in early first trimester medical termination of pregnancy - a prospective study. The New Indian Journal of OBGYN. 2019; 5(2): 10712 
$12-18 \%$ in different states ${ }^{3}$. The majority of induced abortions are performed in the first trimester by Vacuum aspiration with a complete abortion rates of $95-98 \%{ }^{4}$. Immediate abortion related complications, are heavy bleeding (0.01-0.25\%), uterine perforation $(0.01-0.4 \%)$, cervical laceration $(0.01-0.35 \%)$ and anaesthesia related complications ${ }^{5}$. Medical abortion offers an alternative to surgical methods, and some of the complications related to surgery, such as uterine ruptures and cervical tears, as well as anaesthesia related complications can be avoided. Medical abortion induced with a combination of mifepristone and a prostaglandin analogue was licensed and taken into routine use between 1982 and 1992 in France, UK and Sweden, and in 2006 in several European countries ${ }^{6}$. In India, Medical method of termination was approved only in 2002 up to 49days of gestation after the last menstrual period ${ }^{7}$. The MTP act allows the use of medical abortion only up to 49 days of gestation. But after the approval of combipack ( 1 tab of mifepristone and 4 tab of misoprostol 200mg) by the Central Drugs Standard Control Organization, Director General of Health services approve medical termination of pregnancy for up to 63 days of gestation in December 2008, and the Ministry of Health and Family Welfare, Government of India is taking action on modifying the MTP rules in accordance with this approval ${ }^{8}$.

Mifepristone, a synthetic antiprogestin compound, was found to possess high affinity not only for the glucocorticoid receptor but also for the progesterone receptor as well as a weak affinity for the androgen receptor ${ }^{9}$. Mifepristone acts by binding to the progesterone receptor, thus inhibiting the effect of progesterone. The affinity of mifepristone for the human uterine progesterone receptor is twice that of progesterone ${ }^{10}$. The blockade of the progesterone receptor with mifepristone leads to necrosis in capillary endothelial cells in the post-ovulatory endometrium ${ }^{11}$ and in early pregnancy decidua, to increase prostaglandin synthesis ${ }^{12,13}$ and to decrease in the concentration of prostaglandin dehydrogenase $^{14}$. The endogenous prostaglandins produced in the decidua diffuse to the myometrium, where they induce uterine contractions. The sensitivity of the myometrium to exogenous prostaglandins is also increased by administration of mifepristone ${ }^{15,16}$.
Misoprostol is a synthetic prostaglandin $E_{1}$ analogue administered orally for the treatment of peptic ulcers. Misoprostol is stable at room temperature and is inexpensive. Because of its uterotonic and cervicalripening actions, misoprostol is also widely used for various gynaecological and obstetrical purposes, such as for cervical ripening and induction of labour, for pretreatment of the cervix prior to surgical termination of pregnancy and, in combination with mifepristone, for medical abortion ${ }^{17}$. This drug is now widely used for inducing pregnancy terminations and its complete abortion rate has been reported between $61 \%$ and $93 \%$. The effectiveness of this drug is dependent on the dose of usage, following its repeated dose as well as using it in combination with other drugs that led to a complete abortion rate of $98 \%$. After oral administration, misoprostol rapidly de-esterifies to its biologically active form, misoprostol acid. Misoprostol acid is $85 \%$ albuminbound and has a half-life of approximately 30 minutes $^{18}$. The peak serum concentrations of misoprostol acid are reached in 30 minutes after oral and sublingual administration and in 72 minutes after vaginal administration ${ }^{19}$. This is due to rapid absorption through the sublingual mucosa as well as the avoidance of the first pass metabolism. Despite Misoprostol can be used with different routes including oral, sublingual and vaginal, however a few evidences are available in drug effectiveness as well as its related side effects when used in different routes. Hence, the present study aimed to compare the efficacy of misoprostol in combination with mifepristone in first trimester abortion through sublingual and vaginal routes of administration.

\section{Materials and Methods}

After the approval of Institutional Ethical Committee and proper counseling and consent of the patients, this randomized prospective study was conducted at Department of Obstetrics and Gynaecology, Assam Medical College \& Hospital, Dibrugarh, Assam from January 2011 to January 2012. A total of 100 women who fulfilled the inclusion criteria and requested legal termination of pregnancy were randomised into two groups [Group A: Sublingual Misoprostol Group (50 cases), Group B: Vaginal Misoprostol Group (50 cases)].

Inclusion criterias: Gestational age up to $<9$ weeks or 
63 days; single intrauterine pregnancy; patient having immediate access to emergency health services, if required; patient willing to undergo surgical abortion in case of failure or excessive bleeding.

Exclusion criterias: Patient not giving written informed consent; $\mathrm{Hb}<8 \mathrm{gm} \%$; suspected/confirmed ectopic pregnancy; presence of intrauterine device; pregnancy with adnexal mass, coagulopathy, anticoagulant therapy; cardiovascular, renal, liver, respiratory disease and any other known medical disorders.

Drug regime:

Table 1: Drug regime

\begin{tabular}{|c|c|c|}
\hline Day & $\begin{array}{l}\text { Group-A } \\
\text { (Sublingual Misoprostol) }\end{array}$ & $\begin{array}{l}\text { Group-B } \\
\text { (Vaginal Misoprostol) }\end{array}$ \\
\hline Day 1 & Oral mifepristone $200 \mathrm{mg}$ & Oral mifepristone $200 \mathrm{mg}$ \\
\hline Day 3 & Sublingual Misoprostol $800 \mu \mathrm{gm}$ & Vaginal Misoprostol $800 \mu \mathrm{gm}$ \\
\hline Day 15 & $\begin{array}{l}\text { Women were called for follow-up } \\
\text { for history, clinical and ultrasound } \\
\text { evaluation }\end{array}$ & \\
\hline
\end{tabular}

Anti-D was given to $\mathrm{Rh}$ negative women. Data obtained were collected and analyzed statistically by proportions and tests of significance. Statistical significance was set at $\mathrm{p}<0.05$.

\section{Results and Observations}

In Group-A, 64\% were in the gestational age between $50-56$ days, $22 \%$ in $\leq 49$ days and $14 \%$ in 57-63 days when they came seeking termination of pregnancy. In Group-B, 60\% were in the gestational age between 50-56

Table 2: Period of gestation in weeks at the time of request for MTP

\begin{tabular}{lllll}
\hline $\begin{array}{l}\text { Period of } \\
\text { gestation }\end{array}$ & $\begin{array}{l}\text { Group-A } \\
\text { (in days) }\end{array}$ & \multicolumn{2}{l}{$\begin{array}{l}\text { Misoprostol group) } \\
\text { Misoproual }\end{array}$} & \multicolumn{2}{l}{$\begin{array}{l}\text { Group } \\
\text { (Vasoprostol Group) }\end{array}$} \\
& No. & \% & No. & \% \\
\hline$\leq 49$ & 11 & 22 & 12 & 24 \\
$50-56$ & 32 & 64 & 30 & 60 \\
$57-63$ & 07 & 14 & 08 & 16 \\
Total & 50 & 100 & 50 & 100 \\
Mean & 52.58 & & 52.04 & \\
\hline
\end{tabular}

days, $24 \%$ belonged to $\leq 49$ days of gestation, and $16 \%$ were between the gestational age of 57-63 days. Mean gestational age in Group A is 52.58 days (7.5 weeks) and in Group-B is 52.04 days (7.4 weeks) (Table 2).

In Group-A, 66.7\% and in Group-B, 77\% expelled the product within 4-6 hrs. The mean induction to abortion interval in Group A is 4.14 hours and in Group-B is 4.34 hours. Induction abortion time minimum is 3.2 hours and maximum is 7 hours in group-A and in Group-B minimum is 3.3 hours and maximum is 6.15 hours (Table 3).

In Group-A, 96\% and in Group-B, 94\% had complete abortion. There was no case with continuing of pregnancy or missed abortion. The findings in the above table are not statistically significant in both the groups (Table 4). One woman in Group-A had a history of previous lower segment caesarean section and she had complete abortion without any complication.

In Group-A (54.2\%) and in groupB $(61.7 \%)$ had bleeding up to 15 days. Bleeding was heavy for the first two days. Then it was moderate or just spotting thereafter. Median duration of bleeding was similar in both the

Table 3: Induction abortion interval

\begin{tabular}{lllll}
\hline $\begin{array}{l}\text { Induction } \\
\text { abortion interval } \\
\text { in hours }\end{array}$ & $\begin{array}{l}\text { Group-A } \\
\text { (Sublingual } \\
\text { Misoprostol) } \\
\text { No. }\end{array}$ & $\begin{array}{l}\text { Group-B } \\
\text { (Vaginal }\end{array}$ & \multicolumn{2}{l}{$\begin{array}{l}\text { MisoprostolGroup) } \\
\text { No. }\end{array}$} \\
\hline After mifepristone & 0 & 0 & 0 & 0 \\
After misoprostol & & & & \\
2-4 & 14 & 29.1 & 10 & 21 \\
4-6 & 32 & 66.7 & 36 & 77 \\
6-8 & 02 & 4.2 & 01 & 2 \\
TOTAL & 48 & 100 & 47 & 100 \\
Mean \pm SD & $4.14 \pm 1.03$ & $4.34 \pm 0.66$ \\
Median & 4.07 & & 4.2 \\
\hline
\end{tabular}

groups (Table 5). There were 2 incomplete abortion in Group-A and 3 in Group-B and so duration of bleeding was not counted for those cases. All the cases of incomplete abortion in both groups subsequently had undergone dilatation and evacuation to complete the abortion process. Women in Group-A (64\%) had nausea compared to Group-B, (32\%). 'P' value is $<0.001$ which 
Table 4: Outcome

\begin{tabular}{llll}
\hline Outcome & $\begin{array}{l}\text { Group-A } \\
\text { (Sublingual } \\
\text { Misoprostol) }\end{array}$ & $\begin{array}{l}\text { Group-B } \\
\text { (Vaginal } \\
\text { Misoprostol ) }\end{array}$ & $\begin{array}{l}\text { P } \\
\text { value }\end{array}$ \\
& No (\%) & \\
\hline Complete Abortion & $48(96 \%)$ & $47(94 \%)$ & 0.65 \\
Incomplete Abortion & $02(4 \%)$ & $03(6 \%)$ & $>0.05$ \\
Total & $50(100 \%)$ & $50(100 \%)$ & \\
\hline
\end{tabular}

Group-B complained of chill. Statistical analysis of the data shows highly significant difference between the two with' p' value of $<0.003$. Lower abdominal pain in both the groups were similar and there was no statistical difference found between the two (Table 6).

Discussion

The study compared the efficacy and side effects of sublingual and vaginal administration of misoprostol in combination with mifepristone in medical abortion up to 63 days of gestation. The findings suggest mean gestational age in weeks is similar in sublingual (7.4wk) and vaginal $(7.5 \mathrm{wk})$ route when compared with the study done by Tang $(7.7 \mathrm{wk}){ }^{20}$. Median induction to abortion interval shows no significance in induction to abortion interval in both the groups ${ }^{20}$. Also there was no significant difference in the efficacy of the two routes with other studies as done by Tang et $\mathrm{al}^{20}$ and Hamoda et $\mathrm{al}^{21}$.

It has also been reported that induction to abortion interval significantly increases with advanced gestation ${ }^{22}$.The median duration of bleeding in days in our study was 14.65 in sublingual and 14.69 in vaginal group which was slightly lesser when compared with a study done by Tang ${ }^{20}$. Outcome seen with other authors Tang et al. ${ }^{20}$ and Hertzen et al. ${ }^{23}$ are almost similar with the present study. Regarding the route of administration, sublingual is an effective alternative to vaginal administration, although the prevalence of side effects was higher in the sublingual group $^{23,24}$. The majority of the women were managed as day care cases. Hertzen et al ${ }^{23}$ found that median time from misoprostol administration to abortion was 1 hour shorter in sublingual group compared to vaginal. Vaginal administration of 800 microgram of misoprostol remains an important option for medical abortion, as fewer women reported adverse effects in the vaginal group in the present as well as in the previous study.

\section{Conclusion}

Sublingual and vaginal misoprostol after pre-treatment with mifepristone are both effective methods of medical abortion up to 63 days of gestation. In order to reduce the incidence of side-effects, a lower dose of misoprostol can be considered when given sublingually. However, further randomized trials are required to find the optimal dose of sublingual misoprostol that can give highest complete 
abortion rate with minimal side effects. The success of the method lies in the eligibility of the patient to undergo medical abortion with proper dose schedule. So, awareness and knowledge among people regarding medical abortion is important as misuse of drugs leading to failure of abortion not only increases the morbidity and mortality but also the doubt about the efficacy of the method among common people.

\section{Conflict of interest: None. Disclaimer: Nil.}

\section{References}

1)Mankeker K. Abortions- A social dilemma. New Delhi: Vikas Publ. House PVT Ltd; 1973.

2)Chaudhari SK. Fertility control. New Delhi: Elsevier; 2001 .

3)FOGSI. FOGSI Focus 2011- Medical Abortion. Mumbai: FOGSI; 2011.

4)Westfall JM, O’Brien-Gonzales A, Barley G. Update on early medical and surgical abortion. J Womens Health. 1998; 7(8): 991-5.

5)WHO Scientific Group. Medical methods for termination of pregnancy. Report of a WHO Scientific Group. WHO Technical Report Series. Zeneva; 1997.

6)Honkanan K. Medical abortion with mifepristone and misoprostol in first trimester abortion [dissertation]. Helsinki: Helsinki University; 2004.

7)Ashima T, Vinita A, Shalini R. Early medical abortion: a new regimen up to 49 days' gestation. Aust N Z J Obstet Gynaecol. 2005 Apr;45(2):137-9

8)National Rural Health Mission. Comprehensive abortion care, training and service delivary guidelines. New Delhi: Ministry of Health and Family Welfare, Govt of India; 2010.

9)Philibert D, Moguilewsky M, Mary 1, Lecaque D, Secchi J, Deraedt R. Pharmacological profile of RU 486 in animals. In: The Antiprogestin Sreoid RU 486 and Human Fertility Control. Baulieu EE, Segal SJ (eds), New York: Plenum Press; 1985 pp. 49-68.

10)Lahteenmaki P, Heikinheimo O, Croxatto H, Spitz I, Shoupe D, Birgcrson L, Luukkainen T. Pharmacokinetics and metabolism of RU 486. J Steroid Biochem 1987; 27: 859-63.
11)Johannisson E, Oberholzer M, Swahn ML, Bygdeman M. Vascular changes in the human endometrium following the administration of the progesterone antagonist RU 486. Contraception. 1989; 39: 103-17.

12)Norman JE, Kelly RW, Baird DT. Uterine activity and decidual prostaglandin production in women in early pregnancy in response to mifepristone with or without indomethacin in vivo. Hum Reprod. 1991; 6: 740-4.

13)Cheng L, Kelly RW, Thong KJ, Hume R, Baird DT. The effect of mifepristone (RU486) on the immunohistochemical distribution of prostaglandin $\mathrm{E}$ and its metabolite in decidual and chorionic tissue in early pregnancy. J Clin Endocrinol Metab. 1993a; 77: 873-7.

14)Cheng L, Kelly RW, Thong KJ, Hume R, Baird DT. The effects of mifepristone (RU486) on prostaglandin dehydrogenase in decidual and chorionic tissue in early pregnancy. Hum Reprod. 1993b; 8: 705-9.

15)Bygdeman M, Swahn ML. Progesterone receptor blockage. Effect on uterine contractility and early pregnancy. Contraception. 1985; 32(1): 45-51.

16)Swahn ML, Bygdeman M. The effect of the antiprogestin RU 486 on uterine contractility and sensitivity to prostaglandin and oxytocin. BJOG. 1988; 95: 126-34.

17)Goldberg AB, Greenberg MB, Darney PD. Misoprostol and pregnancy. N EngI J Med 2001; 344: 38-47.

18)Garris RE, Kirkwood CF. Misoprostol: a prostaglandin El analogue. Clin Pharm. 1989;8: 627-44

19)Garris RE, Kirkwood CF. Misoprostol: a prostaglandin El analogue. Clin Pharm 1989;8:627-44

20)Tang O, Chan C, Ng E, Sharon L, Ho P. A prospective, randomised, placebo-controlled trial on the use of mifepristone with sublingual or vaginal misoprostol for medical abortions of less than 9 weeks gestation. Human Reproduction. 2003; 18(11): 2315-8.

21)Hamoda H, Premila.W, Ashok, Fleet M, Templeton A. A randomised controlled trial of mifepristone in combination with misoprostol administrered sublingually or vaginally for medical abortion up to 13 weeks of gestation. BJOG. 2005; 122: 1102-8.

22)Ashok PW, Templeton A, Wagaarachchi PT, Flett GM. Factors affecting the outcome of early medical abortion: a review of 4132 consecutive cases. BJOG 2002; 109(11): 1281-9. 
23)Hertzen H, Huong NTM, Piaggio G, Bayalag M, Cabezas E, Fang AH, Gemzell-Danielsson K, Hinh ND, et al for WHO Research Group on post ovulatory Methods of Fertility Regulation. Misoprostol dose and route after mifepristone for early medical abortion: a randomised controlled noninferiority trial. BJOG. 2010; 117: 1186-96.

24)Hamoda H, Ashok P, Dow J, Flett GMM, Templeton A. A pilot study of mifepristone in combination with sublingual or vaginal misoprostol for medical termination of pregnancy up to 63 days gestation. Contraception. 2003; 68: 335-8.
B. L Pathak ${ }^{1}$, Shikha Hajong Roy ${ }^{2}$

${ }^{1}$ Retd. Associate professor, Department of Obstetrics and Gynaecology, Assam Medical

College, Dibrugarh, Assam; ${ }^{2}$ Private Practice, Obstetrics and Gynaecology, Bangalore,

Karnataka, India. 